\title{
Program Kemitraan Masyarakat Pada Kelompok Perajin Perak Dharma Batubulan, Kabupaten Gianyar
}

\author{
IA Cynthia Saisaria Mandasari ${ }^{1}$, N Paramananda ${ }^{2}$, Ni Luh Made Mahendrawati ${ }^{3}$ iD \\ ${ }^{1,2}$ Fakultas Ekonomi dan Bisnis Universitas Warmadewa, Denpasar, Indonesia \\ ${ }^{3}$ Fakultas Hukum Universitas Warmadewa, Denpasar, Indonesia \\ *Corresponding author: Mandasari89@gmail.com
}

\begin{abstract}
Abstrak
Kunjungan wisatawan menurun, misalkan seperti saat low season, ini juga akan memberikan dampak penurunan penjualan bagi para penjual. Fenomena ini tentu akan berpengaruh langsung kepada Kelompok perajin peraki.Tujuan pengabdian untuk mengatasi masalah penurunan pemasaran, ketergantungan mantra, mengubhan teknik pemasaran dan mengatasi perselisihan atar konsumen. Jenis kegiatan ini adalah kemitraan kepda masyarakat. Mitra pengabdian ini adalah kelompok perajin beranggotakan 12 orang ini mengerjakan berbagai jenis perhiasan berbahan perak yang dipesan kemudian dikirimkan ke mitra yakni UC Silver. Kegiatan pengabdian yang dilakukan adalah pendampingan, strategi pemasaran dan strategi penanggulangan perselisihan dengan konsumen. Hasil menunjukkan adalah strategi digital marketing yang kami berikan pada Kelompok Perajin Perak Dharma memiliki dampak peningkatan penjualan dan perluasan pangsa pasar. Implikasi PKM ini dapat digunakan sebagai masukan bagi Kelompok Perajin Perak Dharma untuk membenahi pemasaran produknya.
\end{abstract}

Kata Kunci: Penurunan Penjualan, Digital Marketing, Pendampingan

\section{Abstract}

Decreased tourist visits, for example during low season, this will also have an impact on decreasing sales for sellers. This phenomenon will certainly have a direct effect on the craftsmen group. The purpose of this service is to overcome the problem of declining marketing, dependence on mantras, changing marketing techniques and overcoming disputes between consumers. This type of activity is a community partnership. This service partner is a group of 12 craftsmen who work on various types of silver jewelry that are ordered and then sent to partners, namely UC Silver. The service activities carried out are mentoring, marketing strategies and strategies for dealing with disputes with consumers. The results show that the digital marketing strategy that we provide to the Silver Dharma Crafts Group has the impact of increasing sales and expanding market share. The implications of this PKM can be used as input for the Silver Dharma Crafts Group to improve the marketing of its products.

Keywords: Sales Decrease, Digital Marketing, Mentoring

\section{INTRODUCTION}

Negara Indonesia merupakan negara yang memiliki keanekaragaman budaya. Tiap daerah atau masyarakat mempunyai corak dan budaya masing-masing yang memperlihatkan ciri khasnya. Hal ini bisa dilihat dari berbagai bentuk kegiatan sehari-hari, misalnya upacara ritual, pakaian adat, perhiasan, bentuk rumah, kesenian, bahasa, dan tradisi lainnya (Riskyawan \& Ervianty, 2019). Salah satu jenis budaya yang terkenal hingga ke mancanegara adalah perhiasan perak dengan ukiran khas budaya Pulau Bali. Kerajinan perak sendiri memiliki kelebihan diantaranya memiliki harga bahan baku yang relatif lebih murah sehingga akan memberikan kemudahan untuk pelaku usaha karena modal yang dibutuhkan untuk masuk kedalam industri ini lebih terjangkau (Putra \& Ardana, 2016). Saat ini pengembangan berbagai jenis desain dan motif perak di sentra-sentra produksi di Bali dapat dikatakan telah mengacu pada pemanfaatan bahan baku berstandar perdagangan dunia/ekspor. Salah satu kelompok perak yang ada di Bali adalah Kelompok perajin perak Dharma Batubulan menjadi mitra yang disasar dalam program pengabdian kepada masyarakat ini. Bapak Ketut Darma merupakan

$\begin{array}{ll}\text { History: } & \\ \text { Received } & \text { : April 10, } 2021 \\ \text { Revised } & \text { : April 12, } 2021 \\ \text { Accepted } & \text { : May 03, } 2021 \\ \text { Published } & \text { : May 25, } 2021\end{array}$


ketua dari Kelompok perajin perak Dharma Batubulan, kelompok perajin ini beranggotakan 12 orang ini mengerjakan berbagai jenis perhiasan berbahan perak yang dipesan kemudian dikirimkan ke mitra yakni UC Silver. Dalam sebulan memiliki rata-rata penghasilan bulanan tiga juta rupiah per orang dari pemesanan oleh mitranya yakni UC Silver yang merupakan salah satu destinasi yang dikunjungi oleh para wisatawan.

Sebagai daerah pariwisata, tinggi rendahnya penjualan tergantung pada jumlah wisatawan yang berkunjung. Saat jumlah kunjungan wisatawan tinggi, maka penjualan akan meningkat dan memberikan keuntungan bagi penjual (Filieri, 2015). Namun, apabila kunjungan wisatawan menurun, misalkan seperti saat low season, ini juga akan memberikan dampak penurunan penjualan bagi para penjual. Fenomena ini tentu akan berpengaruh langsung kepada Kelompok perajin perak Dharma Batubulan, Kabupaten Gianyar. Secara umum masalah yang dihadapi oleh mitra antara lain terjadi penurunan pemesanan oleh mitra saat low season karena berkurangnya kunjungan para wisatawan, masih bergantung pada mitra, strategi pemasaran yang masih menggunakan teknik pemasaran yang masih manual, dan seringkali terjadi perselisihan dengan konsumen terkait hal-hal tertentu. Upaya meningkatkan daya saing salah satu komoditi andalan Bali ini di kancah persaingan dunia, sudah tentu para produsen harus terus berbenah, membenahi manajemen produksi, mengadopsi promosi digital, tak kalah esensial adalah memacu kreativitas para pemotif agar mampu menghasilkan karyakarya desain dan motif yang unik dan menarik. Jadi, solusi yang bisa dilakukan adalah dengan melakukan digital marketing.

Pemasaran digital juga menjadi media baru dengan kapasitas multimedia interaktif yang besar, menggabungkan faktor psikologis, kemanusiaan, antropologis, dan teknologi (Jasmani et al., 2019). Pemasaran digital merupakan bagian dari komunikasi pemasaran (Hadi \& Ardhi Khairi, 2020). Konsep digital marketing adalah memanfaatkan area luas pada media seperti perangkat mobile hingga Internet, dimana media tersebut akan memberikan infografis tentang berbagai produk yang dipasarkan oleh perusahaan, terutama penekanan tentang merek sebuah barang atau jasa (Arifin et al., 2019; Jara \& Putra, 2021; Naimah et al., 2020). Penggunaan internet dan media sosial telah mengubah perilaku konsumen dan cara perusahaan menjalankan bisnisnya (Kannan \& Li, 2017). Pemasaran sosial dan digital menawarkan peluang signifikan bagi organisasi melalui biaya yang lebih rendah, kesadaran merek yang lebih baik, dan peningkatan penjualan (Dwivedi et al., 2021). Media yang sering digunakan dalam digital marketing adalah media sosial seperti: Facebook, Instagram dan Whatsapp (Munarsih et al., 2020). Digital marketing menjadi sarana paling ampuh untuk meningkatkan penjualan.. Tentu sangat jauh lebih unggul dibandingkan dengan marketing konvensional yang terbatas waktu, lokasi, dan jangkauan pengguna. Beberapa penelitian yang berkaitan dengan digital marketing antara lain, Penelitian yang menyatakan bahwa online marketing campaign berpengaruh secara signifikan pada kelima variabel AISAS dan berdasarkan koefisien determinasi ditemukan bahwa online marketing campaign mempengaruhi variabel search dengan (Putri \& Fithrah, 2018). Penelitian menyatakan bahwa terdapat pengaruh yang positif variable e-commerce terhadap variable keputusan pembelian (Mewoh et al., 2019). Penelitian yang menyatakan bahwa menunjukkan kontribusi pemasaran digital untuk meningkatkan pendapatan warga desa pasca Covid-19 (Maria et al., 2021). Penelitian yang menyatakan bahwa terdapat hubungan yang positif dan signifikan antara variabel digital marketing terhadap brand awareness(Millennium et al., 2021). Jadi berdasarkan jabaran tersebut dengan adanya digital marketing berpengaruh terhadap pemasaran. Oleh sebab itulah alasan pengabdian ini yang bertujuan untuk mengatasi masalah penurunan pemasaran, ketergantungan mantra, mengubhan teknik pemasaran dan mengatasi perselisihan atar konsumen.

Target luaran yang diharapkan setelah adanya pengabdian masyarakat di Kelompok perajin perak Dharma Batubulan ini adalah pembuatan model digital marketing untuk memudahkan pemasaran hasil kerajinan perak kepada para pembeli yang hanya tinggal 
menunggu dirumah tanpa harus berpergian. Penggunaan metode ini juga dapat didukung dengan jasa pengiriman online yang saat ini sudah tersedia di Indonesia, seperti JNE, J\&T, Gosend dan Grab delivery, sehingga pangsa pasar dapat diperluas lagi. Apabila terjadi permasalahan dalam proses pembelian secara online ini, pengurus Kelompok perajin perak Dharma Batubulan dapat menyelesaikannya dengan tata cara penyelesaian preventif dan represif terhadap perselisihan yang terjadi dengan konsumen. Tata cara preventif merupakan upaya mencegah terjadinya suatu masalah atau sebelum terjadi, misalnya Kelompok perajin perak Dharma Batubulan memastikan hanya menyediakan kualitas perak yang baik. Hal ini dilakukan agar konsumen yang membeli secara online tidak merasa kecewa. Sedangkan tata cara represif merupakan upaya tindak langsung atau cepat untuk mengatasi masalah yang timbul setelah masalah, misalnya terjadi ketidakpuasan akan perhiasan yang dikirim, maka Kelompok perajin perak Dharma Batubulan menyelesaikan dengan mediasi yaitu siap menggantinya dengan yang baru.

\section{MATERIALS AND METHODS}

Kegitan pengabdian ini bertujuan untuk mengatasi masalah penurunan pemasaran, ketergantungan mantra, mengubhan teknik pemasaran dan mengatasi perselisihan atar konsumen. Mitra dalam pengabdian ini adalah kelompok perajin perak Dharma Batubulan menjadi mitra yang disasar dalam program pengabdian kepada masyarakat ini. Bapak Ketut Darma merupakan ketua dari Kelompok perajin perak Dharma Batubulan, kelompok perajin ini beranggotakan 12 orang ini mengerjakan berbagai jenis perhiasan berbahan perak yang dipesan kemudian dikirimkan ke mitra yakni UC Silver. Dalam sebulan memiliki rata-rata penghasilan bulanan tiga juta rupiah per orang dari pemesanan oleh mitranya yakni UC Silver yang merupakan salah satu destinasi yang dikunjungi oleh para wisatawan. Kegiatan pengabdian ini terdiri 3 (tiga) yaitu pertama, memberikan pendampingan. Memberikan pendampingan dan konsultasi mengenai kemungkinan yang akan dihadapi saat terjadi pengurangan jumlah kunjungan wisatawan saat low season. Pendampingan ini bisa memberikan pemahaman dampak yang mungkin timbul dan risiko yang akan mereka hadapi ketika terjadi penurunan penjualan saat itu. Selain itu, pendampingan ini juga akan diiringi dengan pembinaan cara untuk menanggulangi dampak risiko yang dihadapi tersebut. Kedua, Strategi pemasaran pemasaran sangat penting dalam dunia bisnis karena merupakan bagian yang langsung berhadapan dengan konsumen. Tinggi rendahnya penjualan salah satunya disebabkan oleh faktor pemasaran. Oleh karena itu, kelompok perajin perak akan diperkenalkan dengan digital marketing. Langkah awalnya adalah pembentukan akun media sosial yang diharapkan akan mampu menunjang pemasaran produk kelompok perajin perak Dharma Batubulan tersebut. Kemudian dilakukan pendampingan untuk terus memperbaharui isi dari akun tersebut serta melakukan endorsement guna memberikan informasi terbaru bagi para konsumen dan menambah followers. Ketiga, Strategi penanggulangan perselisihan dengan konsumen. Memberikan pendampingan mengenai strategi perselisihan dengan konsumen dengan tata cara preventif merupakan upaya mencegah terjadinya suatu masalah atau sebelum terjadi, dan tata cara represif yang merupakan upaya tindak langsung atau cepat untuk mengatasi masalah yang timbul setelah masalah, serta aturan hukum dan sanksi yang berlaku.

\section{RESULTS AND DISCUSSION}

Hasil

Kegitan pengabdian ini dilakukan pada tanggal 4 Juni 2021 pertemuan dengan semua peserta pelatihan sesuai protokol Covid-19 yang dihadiri oleh Ketua Kelompok perajin perak 
Dharma Batubulan. Adapun kegiatan yang dilakukan pada saat itu antara lain : 1) Pembukaan kegiatan Program Kemitraan Masyrakat pada Kelompok perajin perak Dharma Batubulan yang menjadi mitra kegiatan ini. 2) Uraian dari Ketua Tim tentang kegiatan Tri Dharma Perguruan Tinggi khususnya kegiatan pengabdian masyarakat Universitas Warmadewa serta rencana kegiatan pelatihan yang akan dilaksanakan sehingga semua peserta dan instruktur yang akan mendampingi selama kegiatan dapat menyamakan persepsi dan kegiatan menjadi lancar. 3) Diskusi dan tanya jawab mengenai permasalahan yang dihadapi mitra, sekaligus merencanakan kegiatan ini yang menunjukan langkah-langkah solusi atas persoalan yang dihadapi. Pendampingan ini bisa memberikan pemahaman dampak yang mungkin timbul dan risiko yang akan mereka hadapi ketika terjadi penurunan penjualan saat itu. Selain itu, pendampingan ini juga akan diiringi dengan pembinaan cara untuk menanggulangi dampak risiko yang dihadapi tersebut.4) Dilakukan penyerahan akun social media @dharmasilverbali, endorse akun, serta bantuan bahan dasar perak yang akan disumbangkan kepada mitra. Pemasaran sangat penting dalam dunia bisnis karena merupakan bagian yang langsung berhadapan dengan konsumen. Tinggi rendahnya penjualan salah satunya disebabkan oleh faktor pemasaran. Oleh karena itu, kelompok perajin akan diperkenalkan dengan digital marketing. Langkah awalnya adalah pembentukan social media yang diharapkan akan mampu menunjang pemasaran produk kelompok perajin perak Dharma Batubulan tersebut. Dan 5) Pembagian modul pembelajaran sehingga peserta pelatihan dapat belajar dan mengikuti pelatihan dengan lebih lancar.

Pada pertemuan ini dilaksanakan kegiatan ceramah sebagai materi penunjang/umum. Untuk kegiatan ini peserta didik diberikan ceramah mengenai, 1) Manajemen pemasaran berupa sistem digital marketing yang diberikan oleh IA Cynthia Saisaria Mandasari, SE.,MM dan N. Paramananda,SE.,MM. 2. Tata cara penyelesaian preventif dan represif terhadap perselisihan yang terjadi dengan konsumen oleh Dr. Ni Luh Made Mahendrawati, SH.,M.Hum. Untuk kegiatan ceramah ini pelaksana menyediakan modul pelatihan yang berisi materimateri dari ceramah di atas. Kegitan ini dapat dilihat pada gambar 1.
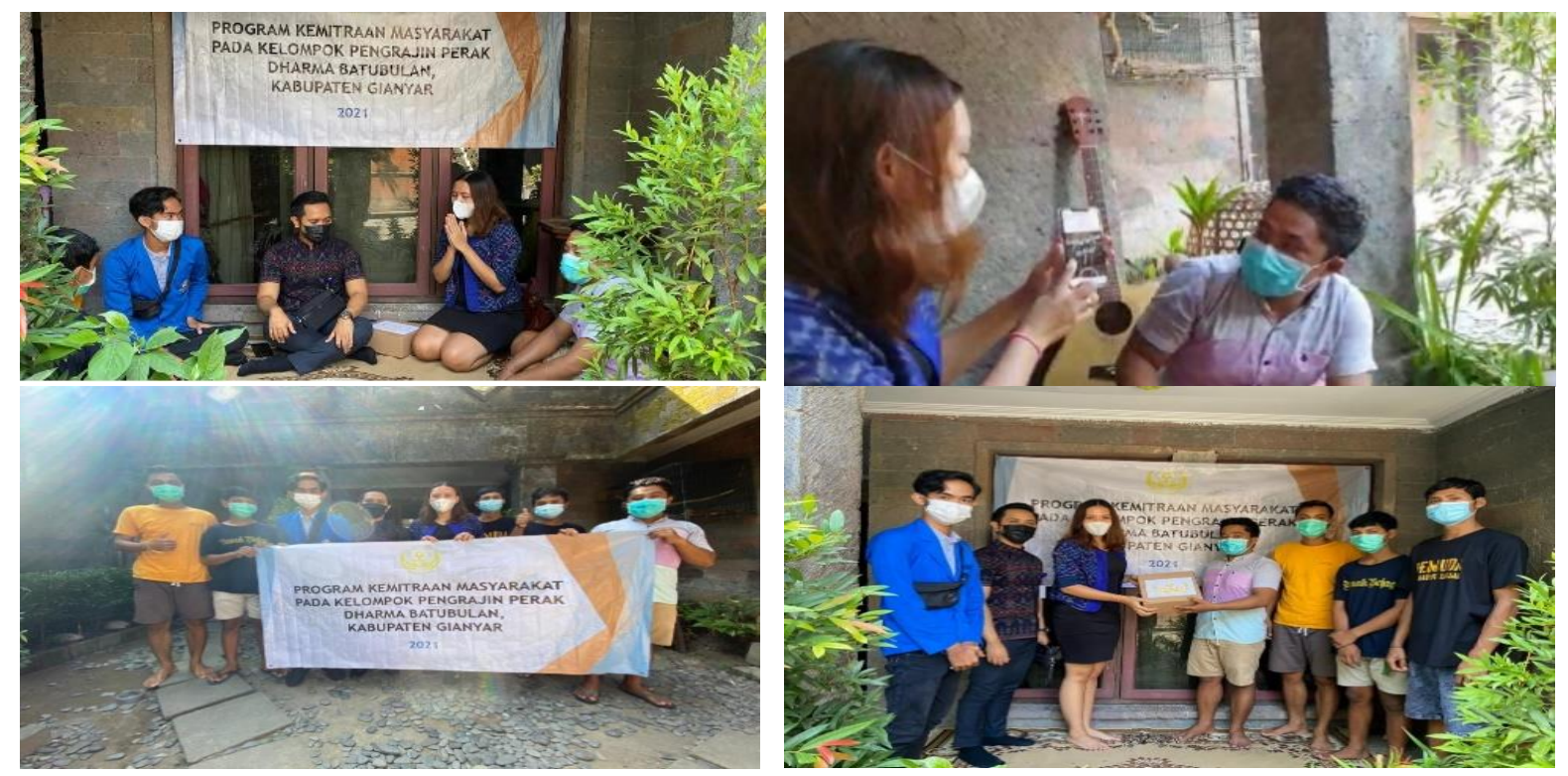

Gambar 1. Kegiatan Ceramah dan Pemberian Bantuan Kepada Mitra

Dengan cara seperti ini diharapkan peserta didik mendapatkan pemahaman mengenai materi ceramah yang berkaitan dengan kewirausahaan dan memiliki file-file yang sewaktuwaktu dapat diambil jika peserta didik lupa dengan teori dan bahan dari pelatihan. Materi diberikan sedemikian rupa sehingga peserta pelatihan akan terbuka wawasannya dan bersemangat untuk mengukuti pelatihan. Pada tanggal 18 Juni 2021, tim pelaksana kembali 
mengunjungi Kelompok perajin perak Dharma Batubulan untuk melakukan evaluasi mengenai bagaimana respon social media yang telah kami berikan. Berdasarkan evaluasi, setelah melaksanakan endorsement, followers akun social media@dharmasilverbali meningkat yang awalnya 3 orang menjadi 208 orang followers. Selain bertambahnya followers, sudah terdapat 11 custom perhiasan yang dipesan melalui akun social media tersebut yang kemudian di proses oleh perajin.

Berdasarkan hasil pengabdian yang dilakukan dapat dikatan bahwa dengan adanya kegiatan pembimbingan dan pemberian materi dapat memberikan pengetahuan yang baru kepada mantra. Kegitan pengabdian akan memberikan wawasan kepada mitra berkaitan dengan teori yang diberikan (Pranoto et al., 2019). Adanya pendampingan dapat memahami potensi dampak dan risiko kehilangan penjualan. Selain itu, pendampingan ini dilengkapi dengan panduan tentang cara mengelola dampak risiko. Dukungan akan membantu memperluas pengetahuan mitra tentang solusi yang mungkin (Januarti et al., 2018; Wardana \& Wulaningrum, 2020). Dengan adanya kegiatan ini mitra diberikan pemahaman akan metode pemasaran yang berbeda dengan sebelumnya. Dimana pemasaran kovensiaonal diubah menjadi digital marketing. Pemasaran digital juga menjadi media baru dengan kapasitas multimedia interaktif yang besar, menggabungkan faktor psikologis, kemanusiaan, antropologis, dan teknologi (Jasmani et al., 2019). Pemasaran digital merupakan bagian dari komunikasi pemasaran (Hadi \& Ardhi Khairi, 2020). Konsep digital marketing adalah memanfaatkan area luas pada media seperti perangkat mobile hingga Internet, dimana media tersebut akan memberikan infografis tentang berbagai produk yang dipasarkan oleh perusahaan, terutama penekanan tentang merek sebuah barang atau jasa (Arifin et al., 2019; Jara \& Putra, 2021; Naimah et al., 2020). Penggunaan internet dan media sosial telah mengubah perilaku konsumen dan cara perusahaan menjalankan bisnisnya (Kannan \& Li, 2017). Pemasaran sosial dan digital menawarkan peluang signifikan bagi organisasi melalui biaya yang lebih rendah, kesadaran merek yang lebih baik, dan peningkatan penjualan (Dwivedi et al., 2021). Dengan pengetahuan yang dimili mitra akan mampu memasarkan produknya lebih luas. Beberapa manfaat dari digital marketing yang dirasakan oleh mitra antara lain digital marketing menjadi sarana paling ampuh untuk meningkatkan penjualan dari mitra dan kelompok perajin perak Dharma Batubulan ini adalah pembuatan model digital marketing untuk memudahkan pemasaran hasil kerajinan perak kepada para pembeli yang hanya tinggal menunggu dirumah tanpa harus berpergian.. Hal ini sesuai dengan beberapa penlitian yang sudah dilakukan penelitian yang menyatakan bahwa online marketing campaign berpengaruh secara signifikan pada kelima variabel AISAS dan berdasarkan koefisien determinasi ditemukan bahwa online marketing campaign mempengaruhi variabel search dengan (Putri \& Fithrah, 2018). Penelitian menyatakan bahwa terdapat pengaruh yang positif variable ecommerce terhadap variable keputusan pembelian (Mewoh et al., 2019). Penelitian yang menyatakan bahwa menunjukkan kontribusi pemasaran digital untuk meningkatkan pendapatan warga desa pasca Covid-19 (Maria et al., 2021). Penelitian yang menyatakan bahwa terdapat hubungan yang positif dan signifikan antara variabel digital marketing terhadap brand awareness (Millennium et al., 2021). Jadi, jabaran ini dapat dikatan bahwa dengan adanya pengabdian ini dapat mengatasi masalah mitra berkaiatan dengan masalah pemasaran.

\section{CONCLUSION}

Kegiatan pengabdian yang dilakukan dinyatakan berhasil hal ini dapat dilihat dari terjadinya peningkatan pemesanan perhiasan perak di kelompok kelompok perajin perak Dharma Batubulan. Pendampingan dan pemberian materi memberikan pengetahuan kepada kelompok perajin perak Dharma Batubulan untuk memasarkan produknya secara luas. 


\section{REFERENCES}

Arifin, B., Muzakki, A., \& Kurniawan, M. W. (2019). Konsep Digital Marketing Berbasis Seo (Search Engine Optimization) Dalam Strategi Pemasaran. EKOMBIS SAINS: Jurnal Ekonomi, Keuangan Dan Bisnis, 4(2), 87-94. https://doi.org/10.24967/ekombis.v4i2.474.

Dwivedi, Y. K., Ismagilova, E., Hughes, D. L., Carlson, J., Filieri, R., Jacobson, J., Jain, V., Karjaluoto, H., Kefi, H., Krishen, A. S., Kumar, V., Rahman, M. M., Raman, R., Rauschnabel, P. A., Rowley, J., Salo, J., Tran, G. A., \& Wang, Y. (2021). Setting the future of digital and social media marketing research: Perspectives and research propositions. International Journal of Information Management, 59(June), 102168. https://doi.org/10.1016/j.ijinfomgt.2020.102168.

Filieri, R. (2015). What makes online reviews helpful? A diagnosticity-adoption framework to explain informational and normative influences in e-WOM. Journal of Business Research, 68(6), 1261-1270. https://doi.org/10.1016/j.jbusres.2014.11.006.

Hadi, A. S., \& Ardhi Khairi. (2020). Pemilihan Strategi Pemasaran Di Era Digital Pada Kelompok Ibu Pkk Desa Gadingharjo. Dinamisia: Jurnal Pengabdian Kepada Masyarakat, 4(1), 127-132. https://doi.org/10.31849/dinamisia.v4i1.3246.

Januarti, I., Mulyana, A., \& Yazid, M. (2018). Pendampingan Pembentukan Koperasi Simpan Pinjam. Jurnal Pengabdian Triwijaya, 710-718. https://ejournal.unsri.ac.id/index.php/jpsriwijaya/article/download/7544/3810.

Jara, L. F., \& Putra, M. R. (2021). Implementasi Digital Marketing dalam Membangun Brand Awareness Menggunakan Metode Object Oriented Analysis and Design pada Umkm Tekstil Kota Padang. Jurnal KomtekInfo, 8(2), 110-117. https://doi.org/10.35134/komtekinfo.v8i2.105.

Jasmani, Maduningtias, L., \& Irmal. (2019). Pelatihan dan Penguasaan Digital Marketing dalam Meningkatkan Pendapatan Para Remaja di Lingkungan Benda Timur IV. A $\gamma \alpha \eta$, 8(5), 55. https://doi.org/10.32493/j.pdl.v2i1.3630.

Kannan, P. K., \& Li, H. “Alice.” (2017). Digital marketing: A framework, review and research agenda. International Journal of Research in Marketing, 34(1), 22-45. https://doi.org/10.1016/j.ijresmar.2016.11.006.

Maria, E., Suharyadi, S., \& Hudiono, R. K. (2021). Implementasi Pemasaran Digital Berbasis Website sebagai StrategiKenormalan Baru Dusun Srumbung Gunung Pasca Covid-19. Riau Journal of Empowerment, 4(1), 1-10. https://doi.org/10.31258/raje.4.1.1-10.

Mewoh, F. M., Tampi, J. R. E., \& Mukuan, D. D. S. (2019). Pengaruh Digital Marketing Terhadap Keputusan Pembelian Pada Matahari Department Store Manado Town $\begin{array}{lllll}\text { Square. Jurnal Administrasi } & \text { Bisnis, }\end{array}$ https://doi.org/10.35797/jab.9.1.2019.23529.35-42.

Millennium, A. S., Suardana, I. W., \& Kusuma Negara, I. M. (2021). Pengaruh Digital Marketing Dan Brand Awareness Terhadap Keputusan Pembelian Pada Startup Bike $\begin{array}{lllll}\text { Rental Bananaz } & \text { Bali. Jurnal }\end{array}$ https://doi.org/10.24843/ipta.2021.v09.i01.p17.

Munarsih, M., Akbar, M. F., Ariyanto, A., Ivantan, I., \& Sudarsono, A. (2020). Pelatihan Digital Marketing Dalam Meningkatkan Kompetensi Siswa Untuk Berwirausaha Pada Smk Muhammadiyah Parung - Bogor. Jurnal Pengabdian Dharma Laksana, 3(1), 22. https://doi.org/10.32493/j.pdl.v3i1.6275.

Naimah, R. J., Wardhana, M. W., Haryanto, R., \& Pebrianto, A. (2020). Penerapan Digital marketing Sebagai Strategi Pemasaran UMKM. Jurnal IMPACT: Implementation and Action, 2(2), 39. https://doi.org/10.31961/impact.v2i2.844.

Pranoto, P., Jasmani, J., \& Marayasa, I. N. (2019). Pelatihan Digital Marketing Untuk Peningkatan Perekonomian Anggota Karang Taruna Al Barkah Di Kampung Cicayur - 
Tangerang. Jurnal Pengabdian Dharma Laksana, 1(2), 250. https://doi.org/10.32493/j.pdl.v1i2.2425.

Putra, I. M. W., \& Ardana, I. K. (2016). Pengaruh Motivasi Serta Lingkungan Kerja Terhadap Kepuasan Kerja Serta Dampaknya Terhadap Produktivitas Perajin Perak. E-Jurnal Manajemen Unud, $5(12)$ $7752-7784$. https://ojs.unud.ac.id/index.php/Manajemen/article/view/24577.

Putri, S. D., \& Fithrah, D. S. (2018). Pengaruh Online Marketing Campaign \#Samyangchallenge Terhadap Consumer Behavior Digital Natives Pengguna Youtube Indonesia. PRofesi Humas: Jurnal Ilmiah Ilmu Hubungan Masyarakat, 1(2), 132. https://doi.org/10.24198/prh.v1i2.11460.

Riskyawan, A. V., \& Ervianty, R. M. (2019). Penggunaan Media Komunikasi Pemasaran Digital sebagai Alat Pencapaian Kesadaran Merek pada Produk Kitchenindo. The International Journal of Applied Business, 3(1), 59-72. https://doi.org/10.20473/tijab.V3.I1.2019.59-72.

Wardana, L. K., \& Wulaningrum, P. D. (2020). Pendampingan Pencatatan Keuangan Terkomputerisasi Koperasi Simpan Pinjam Ibu PKK RT $06 \backslash$ Dusun Sengon Karang RT 06 Argomulyo Sedayu Bantul. ETHOS: Jurnal Penelitian Dan Pengabdian Kepada Masyarakat, 8(2), 154-161. https://doi.org/10.29313/ethos.v8i2.5334. 